\title{
THE BIOSTRATIGRAPHY OF SEDIMENTS DEPOSITED IN THE LAKE KAALI METEORITE IMPACT STRUCTURE, SAAREMAA ISLAND, ESTONIA
}

\author{
LEILI SAARSE, RAIVO RAJAMÄE, ATKO HEINSALU and JYRI VASSILJEV
}

\begin{abstract}
SAARSE, LEILI, RAJAMÄE, RAIVO, HEINSALU, ATKO and VASSILJEV, JYRI 1991. The biostratigraphy of sediments deposited in the Lake Kaali meteorite impact structure, Saaremaa island, Estonia. Bull. Geol. Soc. Finland 63, Part 2, 129-139.

The results of lithological, biostratigraphical and chronostratigraphical studies on the Lake Kaali meteorite impact structure, Estonia (lat $58^{\circ} 22^{\prime} \mathrm{N}$, long $22^{\circ} 40^{\prime} \mathrm{E}$ ) are discussed. Two pollen diagrams and 18 radiocarbon dates from different materials are presented. Due to the small area and deep slopes, Lake Kaali bottom sediments are mixed with allocthonous mineral matter, humus, plant remnants and woody pieces. Pollen records (the extraordinarily high value of Betula pollen in the lowermost spectra, the low Picea pollen frequency and the Quercus pollen maximum) indicate that the meteorite impact catastrophe occurred at about $4000 \mathrm{BP}$. Soon afterwards the crater ring wall was inhabited by Bronze Age man. At about 2900 $-2500 \mathrm{BP}$, the crater lake dried out and the formation of gyttja was replaced by woody peat accumulation. A return to deepwater conditions at the end of the Early Subatlantic chronozone is marked by deposition of clayey calcareous gyttja.

Key words: meteor craters, lake sediments, biostratigraphy, pollen diagrams, absolute age, Holocene, Lake Kaali, Estonia.
\end{abstract}

Leili Saarse, Raivo Rajamäe, Atko Heinsalu and Jyri Vassiljev: Institute of Geology, Acad. Sci. Estonia, 200101 Tallinn, 7 Estonia Avenue, Estonia

\section{Introduction}

The Lake Kaali meteorite impact site and the eight associated smaller meteorite craters (Fig. 1) are the most remarkable geological features on Saaremaa Island and, indeed, in Estonia as a whole. Geological and geophysical studies in the crater area have verified that a huge meteorite, weighting some 1000 tonnes, fell to Earth from the northeast at an angle of about $35^{\circ}$ (Aaloe 1968, Bronshten 1962). In the atmosphere it was heated up and broke into pieces. The largest piece (about 80 tonnes) produced a 22 -metre deep crater with a diameter of 105-110 m (Tiirmaa 1984,
1990). The smaller pieces produced eight dry craters with a diameter of $12-40 \mathrm{~m}$ and a depth of $1-4 \mathrm{~m}$. Altogether $2.5 \mathrm{~kg}$ of iron meteorite material has been collected, including a splinter weighting almost $30 \mathrm{~g}$.

The meteorite origin of Lake Kaali was proposed back in 1927 by I. Reinwald, who found the first iron meteorite splinters in 1937 (see Aaloe 1968, 1977). From sparse geological evidence, I. Reinwald concluded that these craters had been formed 4000-5000 years ago (Aaloe 1981). On the basis of the radiocarbon dates on charcoal collected from the bottom of twin craters Nos $2 / 8(2530 \pm 130 \mathrm{BP}, \mathrm{TA}-19$ and $2660 \pm 250 \mathrm{BP}$, 


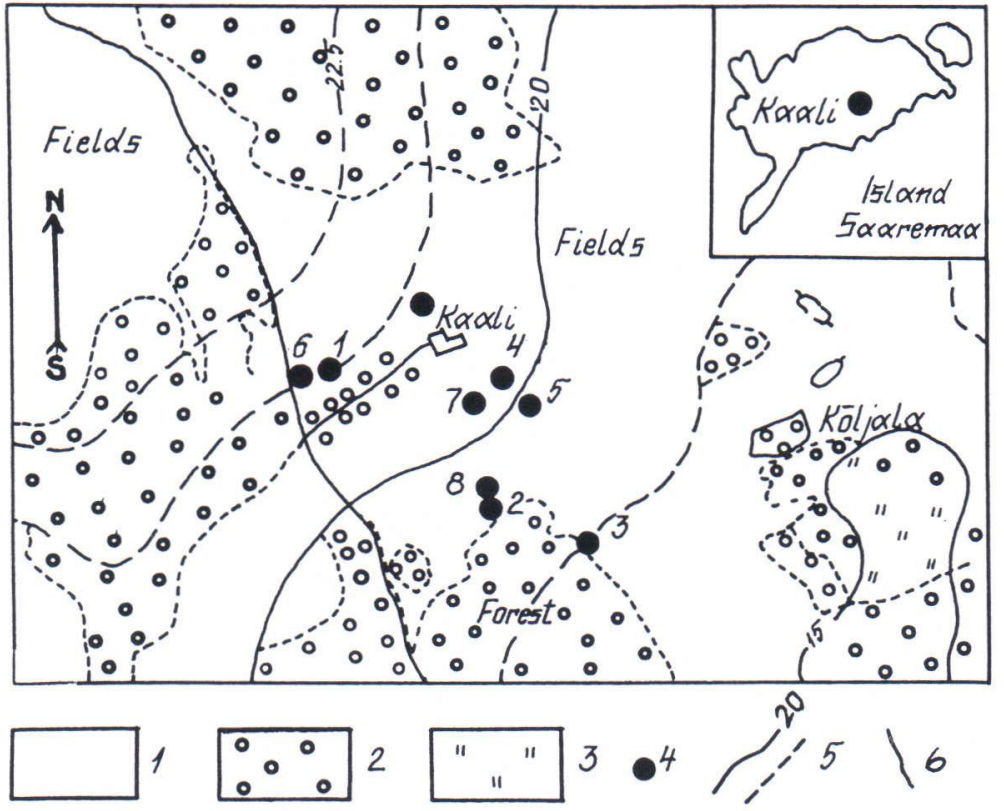

Fig. 1. Scheme of Lake Kaali meteorite crater area at $1: 25000$ scale. Legend: 1 - field, 2 - forest, 3 - meadow, 4 - craters, 5 - isochrones, 6 - road.
TA-22) and from the bottom of crater No. 4 $(2920 \pm 240$ BP, TA-769), Aaloe claimed that the Kaali meteorite craters could not have been formed later than $2800 \mathrm{BP}$., thus setting at least the uppermost age limit (Aaloe 1981).

In 1976-1979, several teams of archaeologists and geologists worked in the Lake Kaali area. The sites of Late Bronze Age and Roman Iron Age settlements, located on and outside the crater wall, were discovered and studied (L-99-ugas $1978,1979,1980)$. The innermost part of the crater wall near the present shoreline was excavated in 1977 . Here the mineral debris, obviously originating from the settlers is covering a layer of gyttja $0.2 \mathrm{~m}$ thick and of peat $0.3 \mathrm{~m}$ thick. An oak stump found buried in peat was dated to $2890 \pm 90 \mathrm{BP}$, Tln-237 (Kessel 1981).

In 1978, the first trial pumping was made, and in 1979 the Kaali sediments were excavated by means of a caisson $2 \mathrm{~m}$ in diameter (Lôugas 1980). A layer of deciduous and coniferous tree trunks, branches, leaves and needles with decomposed organic matter were found under the unconsolidated, 1-1.5 m thick gyttja (Lôugas
1980). The dendrochronological date of an oak trunk from a depth of $2 \mathrm{~m}$ showed that the oak had grown in 1181-1426 AD (Lôugas 1980). The 1-m thick oak trunk brought these caisson experiments to an end and archaeological excavation was suspended for more than 10 years.

The first corings in the lake were made by Ü. Paap and H. Kessel in 1979. Due to the difficulty of penetrating the above-mentioned »wooden floor', only one core was taken for spore and pollen studies. This was later analysed by H. Kessel (manuscript). In 1989 and 1990 two more geological expeditions were organized to Lake Kaali. The sediment stratigraphy was established in two transects, and six cores were taken for further studies in the laboratory. The main results of this research are presented in this paper.

\section{Site description}

Lake Kaali (lat. $58^{\circ} 22^{\prime} \mathrm{N}$, long. $22^{\circ} 40^{\prime} \mathrm{E}$ ) on Saaremaa Island, W. Estonia (Fig. 1), covers an area of $10,500 \mathrm{~m}^{2}$. It is located on Ancylus Lake 


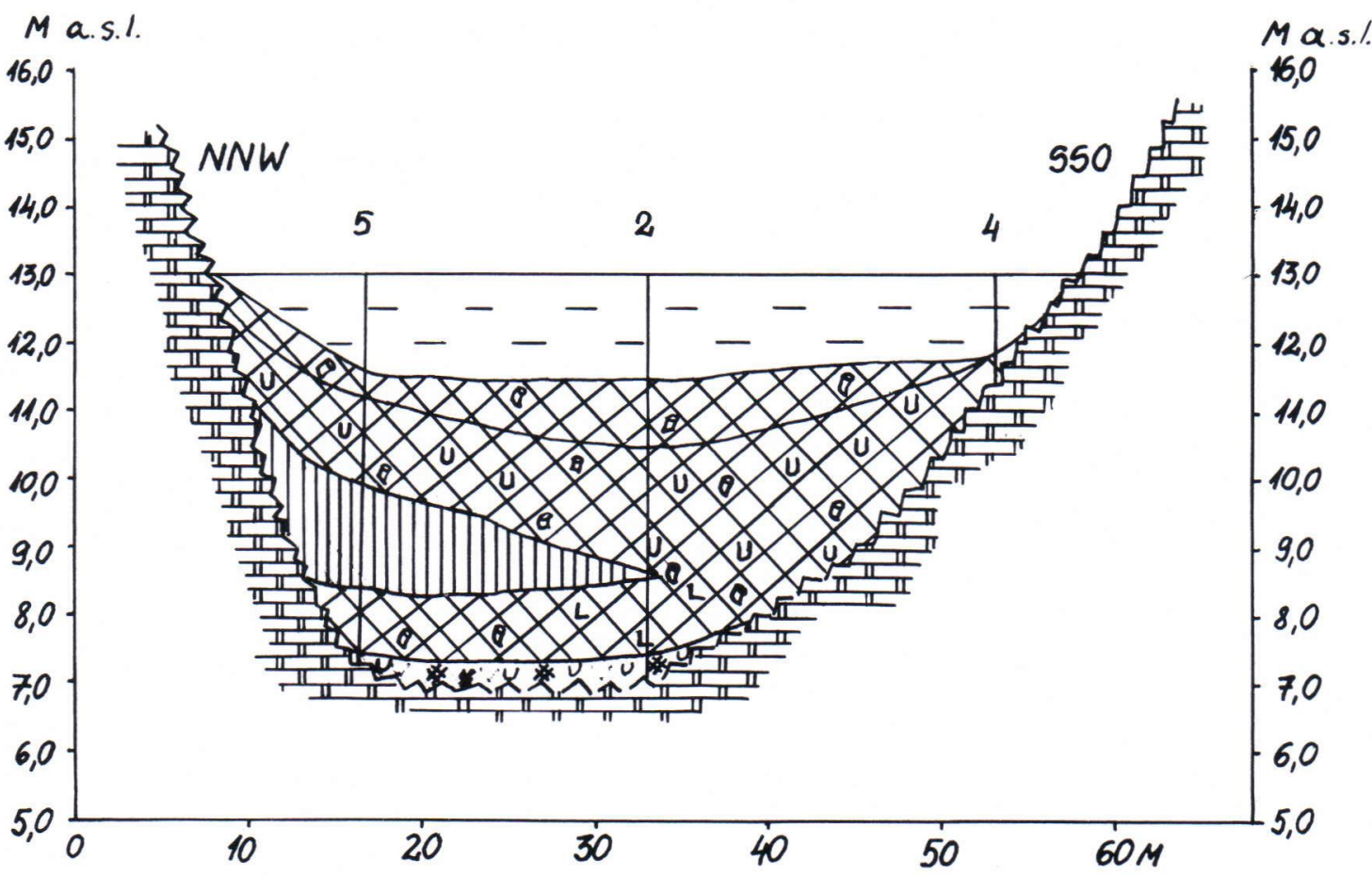

Fig. 2. Simplified section of Lake Kaali. For legend see Fig. 3.

terrace, $18 \mathrm{~km}$ northeast of the town of Kuressaare, at $21 \mathrm{~m}$ a.s.1. Depending on the seasonal lake level, the water surface lies at between 13 and $14 \mathrm{~m}$ a.s.l. The lake is shallow, the average water depth being $1.3 \mathrm{~m}$ (Fig. 2). The basin is 22 $\mathrm{m}$ deep. It reaches Silurian dolomites of the Paadla Formation (Tiirmaa 1990), which disintegrated during the explosion and now form the remarkable ring wall. The crater field is flat and covered with thin till beds, which are largely cultivated.

\section{Field and laboratory methods}

The geological structure of the bottom sediments was clarified in two transects using a Byelorussian peat corer. Two cores were submitted to palynological study, the central one (No. 1) by H. Kessel in 1980 and a marginal one (No. 6) by A. Sarv in 1990.
The pollen slides were prepared using the conventional method. All samples were boiled in $10 \% \mathrm{KOH}$ for $5 \mathrm{~min}$. They were then treated with $10 \% \mathrm{HCl}$, washed, treated with acetic acid and heated in an acetic acid $/ \mathrm{H}_{2} \mathrm{SO}_{4}$ solution at 9:1. After being treated once more with acetic acid, they were washed several times with distilled water. The organic matter content was determined from the loss-on-ignition at $500^{\circ} \mathrm{C}$. The $\mathrm{CaCO}_{3}$ content was calculated from the $\mathrm{CaO}, \mathrm{MgO}$ and $\mathrm{CO}_{2}$ values, and was also determined from the loss-on-ignition at $825^{\circ} \mathrm{C}$.

Radiocarbon dating of the sediments was performed on three fractions of organic matter at Tallinn Radiocarbon Laboratory (Tln). The finest fraction, less than $0.5 \mathrm{~mm}$ and representing autochthonous and allochthonous material, was pretreated with $\mathrm{HCl}$ solution only. Fractions of mainly allochthonous origin, detritic material coarser than $0.5 \mathrm{~mm}$ and woody pieces were pretreated with a conventional AAA method. 


\section{Sediment description and biostratigraphy}

The zonation of the pollen diagrams is based on the principles given in the regional stratigraphical scheme (Kajak et al. 1976). The radiocarbon dates should be viewed with caution for reasons to be discussed later.

Earlier ground magnetic measurements (Aaloe et al. 1976) and recent geological investigations have indicated that the lake basin is asymmetric (Fig. 2), being about $0.4 \mathrm{~m}$ deeper in the northwestern margin than in the central part. The bottommost unit covering the crushed and broken dolomite blocks is very similar to silt and, in the field, was described as silt. Originally it was washed down after the explosion as dolomite dust. This thin allocthonous bed is covered by lake marl (6.30-6.10 m, Fig. 3). The low MgO content and the presence of subfossil mollusc shell fragments are indicative of the limnic origin of this unit. Upwards follows a thin peat layer $(6.10-6.00 \mathrm{~m})$ with calcareous and terrigenous laminae. This thin peat layer may indicate a short-term lowering of the lake level, succeeded by a rather long-lasting higher water level, which, in the sediment record, corresponds to the clayey gyttja bed $(6.0-4.9 \mathrm{~m})$ with some woody pieces and plant macroremnants. The uppermost gyttja $(4.9-4.3 \mathrm{~m})$ is characterised by a gradual increase in total organic matter and a synchronous decrease in the carbonate and clay content (Fig. 4). Subfossil mollusc shell fragments and the abundance of macrofossils are evident of water level lowering, even of complete drying up of the lake, in the Late Subboreal chronozone, when the initial gyttja deposition was interrupted by the subsequent formation of woody peat. The peat is rich in organic matter, with one indicative mineral matter peak at a depth of $3.8-3.9 \mathrm{~m}$ which coincides with the Bronze Age settlement phase and may reflect forest clearance.

Due to the lake level rise in the Early Subatlantic chronozone the basin was filled with water, and clayey calcareous gyttja buried the peat, first in the central, later in the marginal, zone of the lake. The lower part of this unit is enriched in minerogenic matter. The gyttja $(3.0-2.2 \mathrm{~m})$ is variable in composition, consisting at a depth of $2.4-2.9 \mathrm{~m}$ of superimposed twigs and trunks, which made coring difficult. The uppermost gyttja $(2.2-1.7 \mathrm{~m})$, with some mollusc shells and plant remnants, is more calcareous than the topmost unconsolidated gyttja unit $(1.7-1.3 \mathrm{~m})$. The changes in sediment composition may have been caused by lake level fluctuations, by a lowering in SA2 at about $1300 \mathrm{BP}$ or a rise in SA3.

The two palynologically studied cores reveal differences in sediment lithology, stratigraphy and the thickness of the units in the bottommost part of the sequences (Fig. 3). Dolomite dust and lacustrine lime are absent from the central core or they were not described by H. Kessel. The presence of two hiatuses, one between gyttja and lacustrine lime at $6.1-6.0$ and the other between peat and gyttja at $3.2-3.0 \mathrm{~m}$, is obvious in both cores (Fig. 3, core 6).

\section{Primary chronology}

Thirteen radiocarbon dates on different materials - total gyttja, wood, detrital organic material (in fractions coarser and finer than 0.5 $\mathrm{mm}$ ) were determined on the marginal core (Table 1). Together with the known dates, eighteen ${ }^{14} \mathrm{C}$ dates are now available for the Kaali craters. Owing to the small area and steep slopes of the main crater, the bottom sediments are composed of allochthonous organic material, making the radiocarbon ages of sediments younger or older. From time to time trees growing on the rim, have fallen into the lake. Their branches have sunk the unconsolidated beds and been buried in older sediments. Thus the radiocarbon dates of the wood fraction are younger than the sediment age. This is demonstrated by two radiocarbon dates, $1350 \pm 50 \mathrm{BP}$ (Tln-1502) and $740 \pm 60$ BP (Tln-1503), obtained on gyttja and wood, respectively, from the same depth and stratum.

The second process leading to younger dates 
The biostratigraphy of sediments deposited in the Lake Kaali meteorite impact structure...
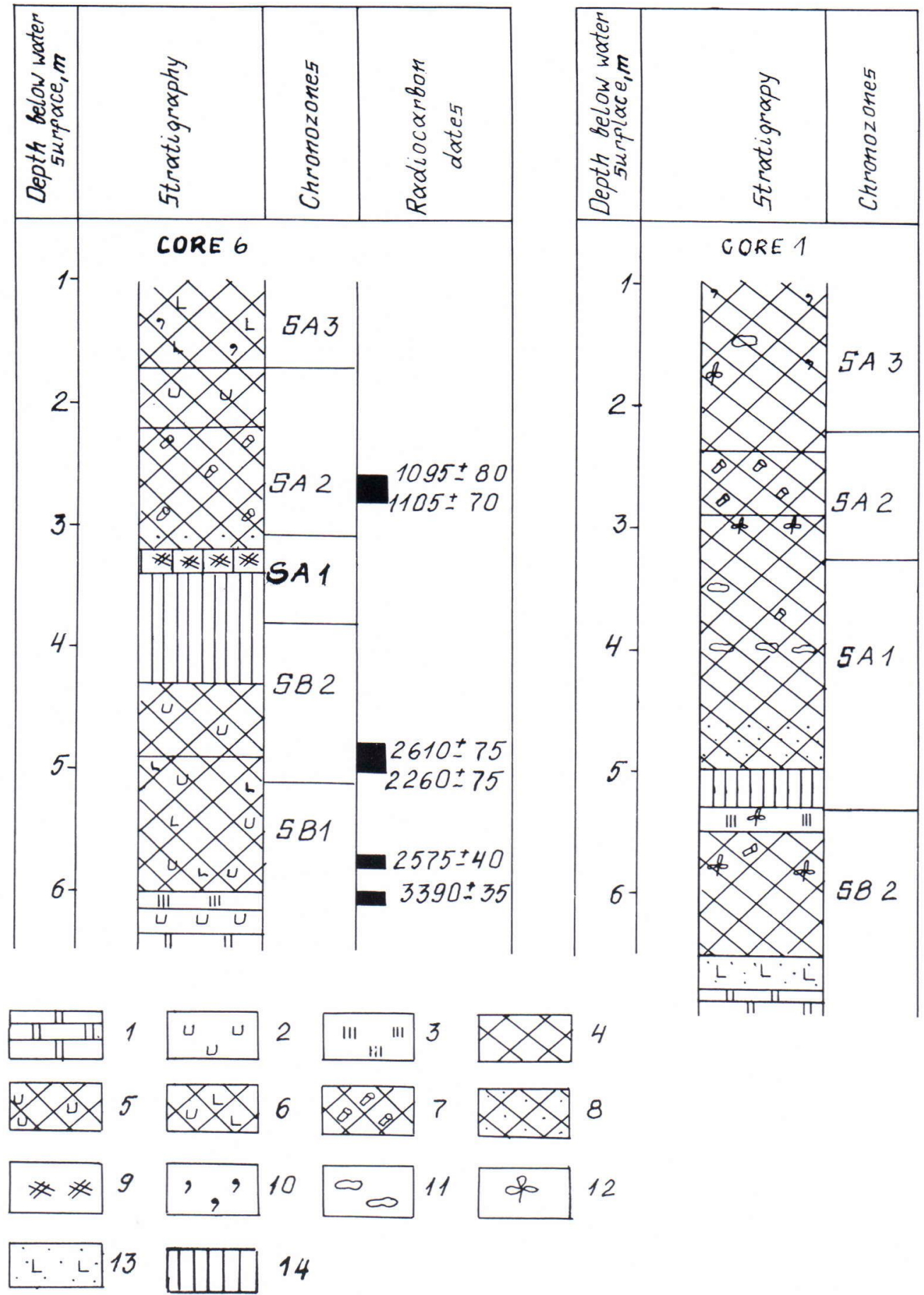

Fig. 3. Late Holocene stratigraphy of two Lake Kaali cores. Legend: 1 - dolomite, 2 - lake marl, 3 - peat, 4 - gyttja, 5 - calcareous gyttja, 6 - clayey calcareous gyttja, $7-$ gyttja with wood trunks, 8 - sandy gyttja, $9-$ peaty gyttja, 10 - subfossil molluscs shells, 11 - carbonate debris, 12 - plant macroremnants, 13 - silty sand, $14-$ peat. 


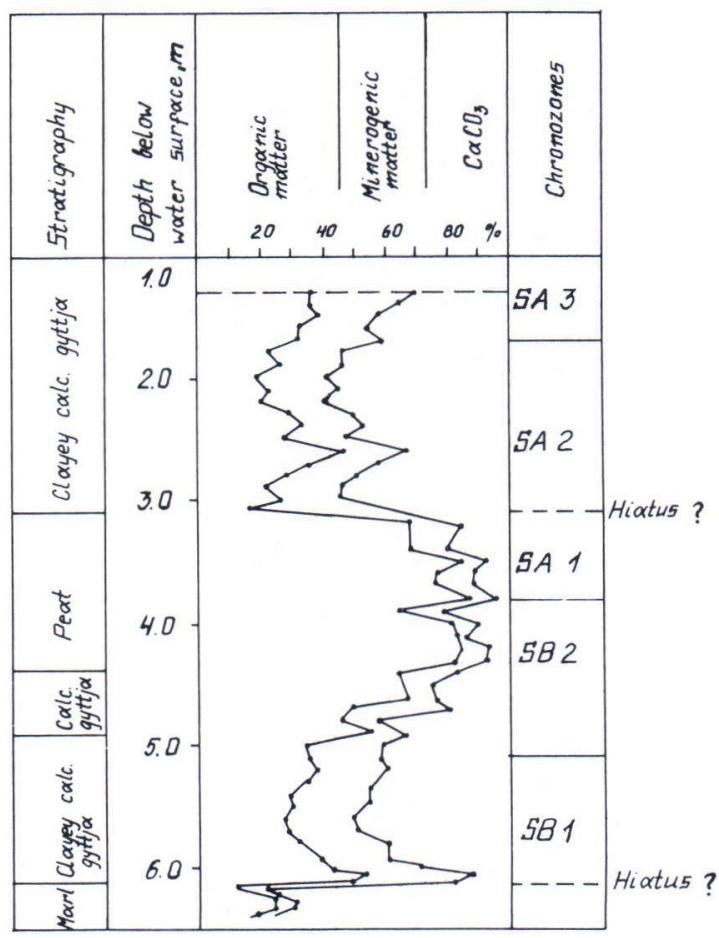

Fig. 4. Stratigraphy of the marginal core ( No 6).

is the contamination by modern humus and detrital organic material washed down from slopes into the deeper sediment layers by bioturbation.
This process affects mainly the radiocarbon age of the finer fraction of sedimentary organic matter. In contrast, organic matter on the slopes may not be modern but may have deposited several hundred years ago causing the radiocarbon dates to be older.

Autochthonous organic matter formed in very hard water has an apparent age of a thousand years or more. As this material is included in the fine fraction of sediment, its age is considerably older than the real one. This is the main reason for the systematic difference in radiocarbon ages between two fraction of organic detrital material.

From the above it can be concluded that the radiocarbon ages of all the fractions of sediments in Lake Kaali are erroneous to a certain extent. Thus our chronological conlusions rely mostly on the local pollen stratigraphy (Kajak et al. 1976).

\section{Pollen analytical results}

Two cores from Lake Kaali were analysed for pollen and spores. As the data on the central core (1) have been published in part (Kessel 1981; manuscript), we concentrated on the marginal core (6), presenting only some comparisions of the two and discussing the consequences. The

Table 1. Radiocarbon dates from the bottom deposits of Kaali craters.

\begin{tabular}{|c|c|c|c|c|}
\hline Core number & Sediment depth & Lab. No. & Age & Material \\
\hline 6 & $2.60-2.70$ & $T \ln -1430$ & $720 \pm 85$ & Fraction $>0.5 \mathrm{~mm}$ \\
\hline 6 & $2.60-2.70$ & Tln-1428 & $1035 \pm 105$ & Fraction $<0.5 \mathrm{~mm}$ \\
\hline 6 & $2.60-2.70$ & Tln-1402 & $1095 \pm 80$ & Wood \\
\hline 6 & $2.70-2.80$ & Tln-1433 & $1105 \pm 70$ & Fraction $>0.5 \mathrm{~mm}$ \\
\hline 6 & $2.70-2.80$ & Tln-1401 & $1660 \pm 80$ & Fraction $<0.5 \mathrm{~mm}$ \\
\hline 6 & $4.80-4.90$ & $T \ln -1431$ & $2610 \pm 75$ & Fraction $>0.5 \mathrm{~mm}$ \\
\hline 6 & $4.80-4.90$ & $T \ln -1427$ & $3055 \pm 55$ & Fraction $<0.5 \mathrm{~mm}$ \\
\hline 6 & $4.90-5.00$ & Tln-1426 & $2260 \pm 75$ & Fraction $>0.5 \mathrm{~mm}$ \\
\hline 6 & $4.90-5.00$ & Tln-1424 & $2565 \pm 85$ & Fraction $<0.5 \mathrm{~mm}$ \\
\hline 6 & $5.70-5.80$ & Tln-1354 & $2575 \pm 40$ & Total org. matter \\
\hline 6 & $6.00-6.10$ & $T \ln -1353$ & $3390 \pm 35$ & Total org. matter \\
\hline Crater $2 / 8$ & 0.5 & TA-19 & $2530 \pm 130$ & Charcoal \\
\hline Crater $2 / 8$ & 1.0 & TA-22 & $2660 \pm 250$ & Charcoal \\
\hline Crater 4 & 1.5 & TA-769 & $2920 \pm 240$ & Charcoal \\
\hline Excav. & upper peat & Tln-237 & $2890 \pm 90$ & Wood \\
\hline Excav. & upper peat & Tln-236 & $2340 \pm 50$ & Peat \\
\hline 7 & $2.45-2.55$ & Tln-1502 & $1350 \pm 50$ & Fraction $<0.5 \mathrm{~mm}$ \\
\hline 7 & $2.45-2.55$ & $T \ln -1503$ & $740 \pm 60$ & Wood \\
\hline
\end{tabular}



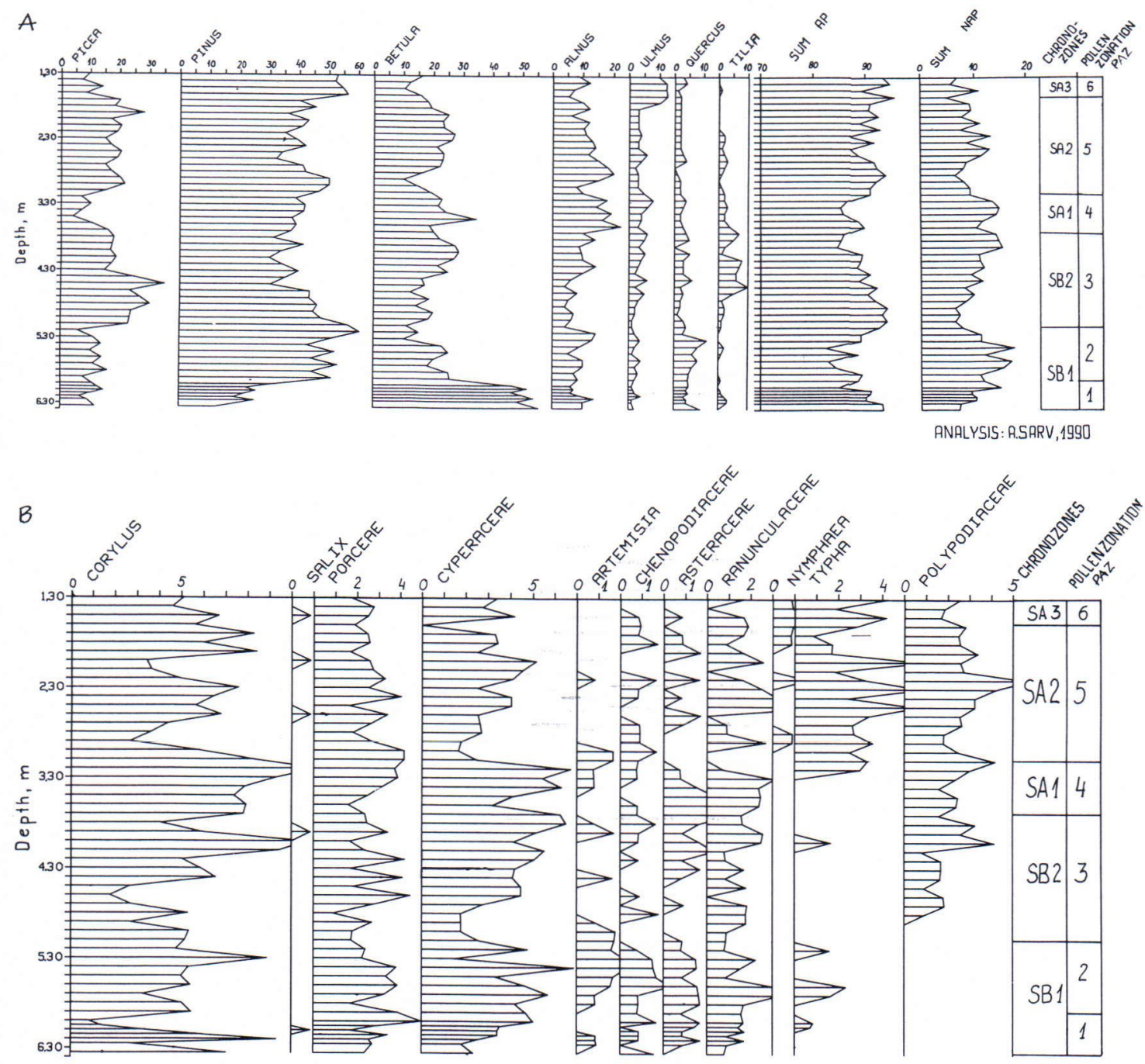

Fig. 5. Simplified pollen diagram of marginal core (No. 6) from Lake Kaali meteorite impact site. A - tree pollen diagram, $\mathrm{B}-$ shrubs and NAP pollen diagram.

material (Fig. 5) enabled us to establish the following local pollen zones (PAZ):
? $\quad 3900$ BP Betula
3900-3700 BP Pinus-Quercus
3700-2800 BP Picea
2800-1700 BP Betula-Alnus-Corylus
1700-1100 BP Picea-Betula
1100-0 BP Pinus

PAZ $1(6.35-6.00 \mathrm{~m})$ differs from the rest ones in its high Betula (50-52\%, Fig. 5) and low Pinus pollen values $(19-23 \%)$. The values for Picea, Alnus and Ulmus pollen are also low. The Tilia profile shows a weak peak and that of Quercus a tendency to rise. These rather specific spectra seem to characterise the post-explosion milieu, when the first plant to invade and cover the burnt area was birch. The total AP (arboreal pollen) value due to birch is high $(90-95 \%)$; the value of NAP is correspodingly low (5-10\%, Fig. 5). 
These spectra are absent from the previous diagram (Kessel, manuscript).

In PAZ $2(6.00-5.10 \mathrm{~m})$ pollen of Pinus and Betula dominates. Pollen of Quercus increases and seems to reach its Early Subboreal (SB1) maximum. The Corylus curve has a distinct peak in the upper part of the zone. The low content of Picea (less than 16\%) and rather high content of Quercus (up to $11 \%$ ) are consistent with their Early Subboreal age. These spectra are also absent from the Kessel's diagram or are represented by only two samples (Kessel, manuscript).

Picea PAZ $3(5.10-3.70 \mathrm{~m})$ is complete and corresponds to SB2. In the middle, the Picea pollen content is high (34\%). Pinus pollen decreases from 60 to $30 \%$, Alnus from 13 to $5 \%$, and Quercus from 11 to $2 \%$. Betula and Corylus percentages differ, the tendency being to increase upwards. The two distinct Tilia peaks are indicative of a new regeneration of Tilia after its common decline at the end of the Atlantic chronozone.

In Betula-Alnus-Corylus PAZ 4 (3.70-3.10 m) Picea pollen decreases (5\%), but the Pinus, Alnus and Betula profiles are rather high. Corylus shows a new expansion, Ulmus forms a slight peak but Tilia gradually diminishes.

Picea-Betula PAZ 5 (3.10-1.70 m) is characterised by the Picea pollen upper Subatlantic maximum (20-30\%). Pinus is clearly dominant $(40 \%)$, and the Betula pollen content is up to $28 \%$. The Alnus pollen value decreases, Ulmus and Quercus are low but stable, and Corylus forms a peak in the middle of the zone.

In the topmost Pinus PAZ $6(1.70-1.30 \mathrm{~m})$, Pinus pollen is dominant, and Ulmus shows a new regeneration. Betula and Alnus pollen values are moderate but variable, while Picea frequencies are low.

\section{Anthropogenic indicators}

Pollen of cultivated plants has been identified in, but not described from, the central core (Kes- sel, manuscript). Cereals, mainly of the Hordeum type appear at the beginning of the Subatlantic (SA1). Secale cereale is present from the midSubatlantic (SA2). Centaurea cyanus pollen appears at the beginning of SA2, at about $1700 \mathrm{BP}$, which was when the fortified settlement was built (Lôugas 1978). Later, only single Centaurea pollen grains occur in gyttja, which accumulated at the transition of SA2/SA3.

The first Polygonum peak in the SB2 could also be attributed to the cultural phase, with Cruciferae pollen originating from either cereal fields or ruderal communities (Behre 1981, Gaillard and Berglund 1988). Their appearance coincide with the Bronze Age settlement. Liguliflorae together with Plantago lanceolata seem to be related to the existence of meadows, pastures or grazed forest land around Kaali.

Chenopodiaceae and Artemisia pollen is present from SB1 (Fig. 5), but they form distinct peaks only on certain levels. Artemisia, Chenopodiaceae and Gramineae indicate a simultaneous rise in the settlement phase (Kessel, manuscript). Plantago pollen is sporadic, occurring first in SB2 together with Liguliflorae and Urti$c a$. The high values of Gramineae (10-19\%), Cyperaceae (up to $11 \%$ ) and the sporadic Plantago in the SB2 pollen spectra can be attributed to the pastoral farming stage preceding the agrarian period after SA1.

\section{Lake level changes}

The variable sediment records, the alternation of lacustrine and terrestrial deposits, and the abundance of macrofossils at a certain level served as a basis for the reconstruction of the major lake level fluctuations. Diatoms are absent (E. Vishnevskaya, pers. comm.). Frustules of only a few taxa - Navicula oblonga, Pinnularia viridis, Amphora ovalis and Cymbella ehrenbergii frustules were found in gyttja at a depth of 2.2-1.9 m.

The deep crater of Lake Kaali, formed in SB1, 


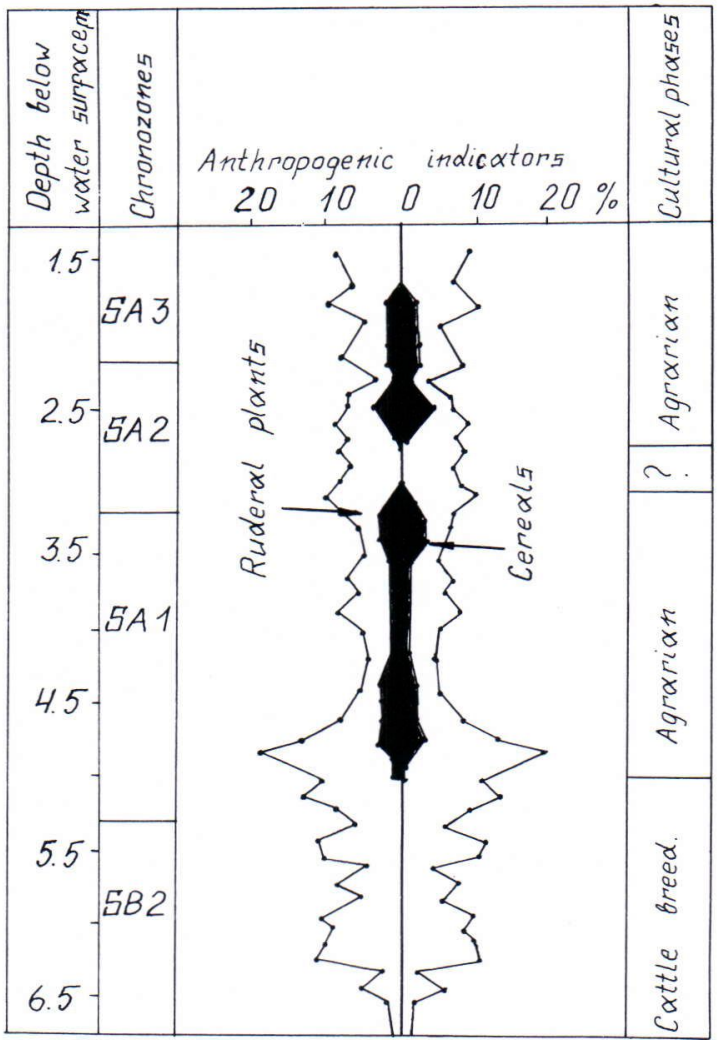

Fig. 6. Human impact diagram of the central core (No. 1).

not later than $4000 \mathrm{BP}$, soon filled with water. Washed-down dolomite dust partly closed the cracks, and groundwater together with precipitation gave rise to a shallow pool in which lake marl and peat accumulated. This period lasted for about 100-200 years. At about 4000-3900 $\mathrm{BP}$, it was succeeded by a drastic rise in water level, obviously up to its present level. During the next period, up to $3600 \mathrm{BP}$, the lake level was more or less stable. After the Late Subboreal chronozone, it began to sink again, reaching its lowest point between 2900 and 1900 BP.

The return to deepwater conditions at the end of SA1, at about $1900 \mathrm{yr}$. BP, is determined by the deposition of clayey calcareous gyttja with minor lowering in the mid-Subatlantic chronozone, at about $1100-1300 \mathrm{BP}$. It is of interest that the major lowering of lake level in the Late
Subboreal chronozone was related to a distinct increase in Corylus pollen. More data are needed before we can come to any conclusions as to whether the dry area developed into an open landscape, readily colonized by Corylus, as in the Early Holocene (Digerfeldt 1988).

\section{Discussion and conclusions}

The Lake Kaali impact site has a very complicated sediment structure. Redeposition, erosion and breaks in sedimentation are clear. The most complete sediment record was obtained from the western margin of the lake. Dolomite dust, lake marl and peat, $0.45 \mathrm{~m}$ thick, are represented by pollen spectra of the Early Subboreal chronozone. The bottommost six spectra are rich in Betula pollen, as is typical of burnt over areas or abandoned slash-and-burn fields (Vuorela 1986). The radiocarbon date of peat $3390 \pm 35 \mathrm{BP}$ (Tln-1353) is too young for this time span. In Estonia the Early Subboreal chronozone is dated back to 4800-3700 BP (Kajak et al., 1976). So, the question of the validity of pollen spectra for reliable interpretation is a topical one. There are three pieces of evidence strongly supporting the conclusion that the pollen spectra of the bottommost beds belong to the Early Subboreal chronozone: 1) the very low value of broad leaved tree pollen; 2) the low Picea pollen frequency, typical of the Early Subboreal part of diagrams, and 3) the Quercus pollen maximum.

These findings indicate that the Kaali impact craters were formed in the Early Subboreal, not later than 4000 years ago. We do not deny that other interpretations and opinions are possible. Our data may be corrected later when our collaborative studies with Danish botanists and archaeologists are completed. The age given earlier - 2800 BP (Aaloe 1981, Aaloe et al. 1963, $1975,1977)$ - for the formation of the Kaali impact craters was based on two radiocarbon dates on charcoal, $2660 \pm 250 \mathrm{BP}$, TA-22 and 2920 \pm 240 BP, TA-769 from dry craters Nos. $2 / 8$ and 
4 respectively (Table 1 ). However, these dates may point to activities of the human beings, who inhabited the crater field area during the Late Bronze Age and may have lit fires in the dry craters for various purposes.

The presence or absence of woody remnants in gyttja also confuses the interpretation of the environmental history. Woody pieces are virtually absent from the ground gyttja bed formed in the Early Subboreal chronozone. Two alternative explanations are postulated. First, during SB1 the crater wall was sparsely forested, as the barren dolomite blocks do not form a suitable substrate for trees. All pollen, the over-represented Pinus in particular, may originate from the surroundings. Second, Bronze Age man, who had erected a settlement just beoynd the crater wall, could have used all the timber for buildings, furnaces and everyday use, thus deforesting the crater rim.

Due to the regional hydrological changes combined with the dryness of the Late Subboreal climate, Lake Kaali was overgrown by peat, trees and bushes for several hundreds of years, the central part at $2900-2500 \mathrm{BP}$, and the marginal zone at 2900-1900 BP. Owing to the low groundwater level (about $10 \mathrm{~m}$ below the surface) and the absence of rivers and lakes in the vicinity, there is a possibility that the Bronze Age man did

\section{References}

Aaloe, A., 1968. Kaali meteoriidikraatrid. Eesti Raamat, Tallinn, $48 \mathrm{p}$.

—, 1977. Môned môtted Kaalist. Eesti Loodus 12, 762-766.

—, 1981. Erinevused Kaali kraatrite vanuse määrangutes. Eesti Loodus 4, 236-237.

Aaloe, A., Dabiza, A. \& Karnauh, B., 1976. Goefizicheskie issledovania na glavnom kratere Kaali. [Geophysical investigations on the main Kaali crater]. Izvestija Academy Nauk ESSR. Khimia, Geologija. [Proceedings Academy of Sciences of ESSR. Chemistry, Geology]. 25, 1, 58-65 (in Russian).

Aaloe, A., Eelsalu, H. \& Liiva, A., Lôugas, V., 1975. Vôimalusi Kaali kraatrite vanuse täpsustamiseks. Eesti Loo- not inhabite Kaali during that time. Artefacts also indicate that the Bronze Age settlement was destroyed and rebuilt during the Iron Age (Lôugas 1978, 1979).

In the uppermost gyttja unit, at $2.4-2.9 \mathrm{~m}$, superimposed stumps form a »wooden floor». When and how this unit was formed is still open to discussion. Does it mean that from 1600 BP Lake Kaali was a holy place (Lôugas 1980), and that a grove of sacred oaks was destroyed by a very heavy storm, or was an attempt made to drain the lake? We do not know. There are several other problems calling for additional studies, for example, detailed anthropogenic indicator and charcoal analyses, AMS radiocarbon dates, and sediment lithostratigraphy. Future studies on neighbouring mires, especially imbedded charcoal layers, could give us more precise information on whether the meteorite fall was accompanied by large-scale forest fires all over Saaremaa or not.

Acknowledgements. The authors wish to thank E. Vishnevskaya, Leningrad State University, for the diatom analyses, A. Liiva for the radiocarbon dates (TA), and L. Säga for the chemical analyses. We are grateful to professor A. Raukas, Dr A. Miidel, A.-M. Rôuk and R. Pirrus for their comments on the manuscript, to Mrs $\mathrm{H}$. Niin for drawing the diagrams and maps, and to Mrs H. Kukk and G. Häkli for improving the English. dus $12,706-709$.

Aaloe, A., Liiva, A.\& Ilves, E., 1963. Kaali meteoriidikraatrite vanusest. Eesti Loodus 5, 262-265.

Aaloe, A., Lôugas, V. \& Saare, E., 1977. Asva linnuse hukkumine. Eesti Loodus 12, 759-762.

Behre, K., 1981. The interpretation of anthropogenic indicators in pollen diagrams. Pollen and Spore, XXIII, 2, $225-245$.

Bronshten, V.A., 1962. Padenie Kaali meorita. [On the fall of the Kaali meteorite]. Meteoritika 22, 42-46 (in Russian).

Digerfeldt, G., 1988. Reconstruction and regional correlation of Holocene lake-level fluctuations in Lake Busjön, South Sweden. Boreas 17, 165-182.

Gaillard, M.-J. \& Berglund, B.E., 1988. Land-use history dur- 
ing the last 2700 years in the area of Bjäresjö, Southern Sweden. In: Birks, Hilary H., Birks, H.J.B., Kaland, P.E., \& Moe, D. (eds.), The Cultural Landscape - Past, Present and Future. Cambridge University Press, Cambridge, 409-428.

Kajak, K., Kessel, H., Liivrand, E., Raukas, A. \& Sarv, A., 1976. Mestnaja rabochaja stratigraficheskaja shema chetvertichnyh otlozenii Estonii. [Regional stratigraphical scheme of the glacial deposits of Estonia]. In: Vaitekunas, P.P. \& Gaigalas, A.J. (eds.), Stratigrafia chetvertichnyh otozenii Pribaltiki [Stratigraphy of the Quaternary deposits of the Peribaltic]. Vilnius, 4-42. (in Russian).

Kessel, H., 1981. Kui vanad on Kaali järviku pôhjasetted? Eesti Loodus 4, 231-235.

Kessel, H. Kaali kraatri järviku pôhjasete vanusest ja holotseeni paleogeograafilistest tingimustest Kagu-Saaremaal. (manuscript).

Lôugas, V., 1978. Archaeological research at Kaali meteorite crater. Eesti Teaduste Akadeemia Toimetised. Ühiskonnateadused 27, 1, 64-66.
—, 1979. Kaali legend ja leiud. Horisont 9, 13-17.

-, 1980. Archaeological excavations in the Kaali crater area. Eesti Teaduste Akadeemia Toimetised. Ühiskonnateadused 29, 4, 357-360.

Saarse, L., Rajamäe, R., Heinsalu, A. \& Vassiljev, J., 1990. Formation of the meteor crater lake Kaali (Island Saaremaa, Estonia). In: Pesonen, L.J. \& Niemisvara, L.H. (eds.), Symposium on Fennoscandian impact structures. Programme and Abstracts. Espoo, 55.

Tiirmaa, R., 1984. Kaali meteoriidikraatrid. Valgus, Tallinn, $16 \mathrm{p}$.

—, 1990. Kaali meteorite craters. In: Kaljo, D. \& Nestor, H. (eds.), Field meeting Estonia 1990: An excursion guidebook. Tallinn, 188-189.

Vuorela, I., 1986. Palynological and historical evidence of slash-and-burn cultivation in South Finland. In: Behre, K.-E. (ed.), Anthropogenic Indicators in Pollen Diagrams. A.A. Balkema, Rotterdam/Boston, 53-64.

Received August 28, 1991

Revision accepted September 6, 1991 